REVIEW ARTICLE

\title{
Some Recent Soviet Publications on Byelorussian Art and Architecture
}

\author{
BY \\ LINDSEY HUGHES
}

Žyvapis Biełarusi XII-XVIII stahoddziaŭ. Compiled by N. F. Vysockaja and T. A. Karpovič. 'Biełaruś', Minsk, 1980. 316 pp.

Ju. A. Jakimovič, Draŭlanaje dojlidstva biełaruskaha Paleśsia XVIIXIX stst. 'Navuka i technika', Minsk, 1978. 151 pp.

M. A. Tkačoŭ, Zamki Biełarusi, 'Połymia', Minsk, 1977. 84 pp.

- Abarončyja zbudavañni zachodnich ziamiel Biełarusi XIII-XVIII stst. 'Navuka i technika', Minsk, 1978. 144 pp.

In recent years we have been treated to a flood of Soviet publications on Byelorussian art, ranging from colourfully illustrated guide books and 'souvenir' editions with minimal texts, through selections from the work of contemporary and pre-revolutionary artists to more sober and scholarly tomes on specialist topics. Father A. Nadson's annual bibliographies in $J B S$ give a fuller idea of the variety. Such publication policy runs parallel to official attempts to collect, restore, preserve and study, although it is clear that much of the loss and damage inflicted over the centuries, the present one included, is irreparable, and one of the major obstacles to drawing conclusions about the history of Byelorussian art and architecture is the pitifully small number of examples which survive from certain genres and periods. This is probably one reason, apart from the allegedly liberating effect of the October Revolution upon the nation's creative powers, why Soviet art receives a disproportionate share of attention. In most Soviet works limitations are also presented by the ideological framework within which authors are obliged to consider even the apparently most politically uncontroversial items. The four works examined below all illustrate these problems to a greater or lesser degree, but all indicate that considerable progress is being made in the study of some fundamental aspects of Byelorussian art history.

For years icon-painting has been one of the most elusive areas of Byelorussian art, its history known in the West from a handful of poorly reproduced examples. Pleasurable expectations are therefore sure to be aroused by the appearance of a book which publishes, amongst other things, over fifty icons in full colour. Visually Żyvapis Biełarusi XII-XVIII stst. is easily the most impressive of the four books, its attractive format indicative of the greatly improved quality 
of paper, colour reproduction and binding of Soviet art books of the past decade. Issued in a print run of 50,000 copies at a price of 14 roubles 50 kopecks, the book is evidently aimed at the foreign reader, who is supplied with partial translations of the Byelorussian captions and an abridged version of the introductory article in Russian, English, French, German and Spanish. The book contains 164 plates on $29 \times 21.5 \mathrm{~cm}$. paper and is divided into chronologically arranged sections on frescoes (ills 1-13), icons (14-108) and portraits (109-64). The notes to each work are conveniently located on facing pages and include concise information on the works' past and present location, the history of discovery and restoration and bibliographical references. Full details are given in Byelorussian only, the foreign captions, which are by and large accurately translated, being confined to brief headings. The reader will be eager to go straight to the illustrations, but N. F. Vysockaja's seven-page introductory article is worth a glance if only to discover some of the old preconceptions which lurk beneath the glossy modern format. One of the stumbling-blocks to a fuller assessment of Byelorussian religious art has always been the Orthodox versus Catholic dilemma, which has frequently been reduced to the simplistic formula that Orthodox art was more truly national and 'progressive' and therefore more worthy of attention. Examples of both are illustrated in this book, but misunderstandings persist. On p. 5, for example, we are told that the majority of Orthodox and Uniate church frescoes were painted by local artists, Catholic ones by foreigners, and a footnote supplies a list of the latter (divided into Jesuits, without indication of nationality, and others). Yet it is impossible to draw any comparative stylistic conclusions from the materials provided since only two Orthodox churches are represented - the 12th-century Cathedral in the Monastery of the Saviour in Polack and the 16th-century Church of the Annunciation at Supraśl, the latter's paintings strongly influenced by Serbian art. All the illustrations of $16 \mathrm{th}-18$ th-century frescoes come from Catholic churches. A further variation on the Orthodox/Catholic theme is found in the assertion (p. 14, English text) that in the 17th century 'the Byelorussian people's struggle against internal oppression increased realistic trends in icon-painting'. The conventional Soviet proposition that liberation struggles generate realism in art requires fuller demonstration (why not escapist fantasy or pure ornamentalism?), whilst the tendency to dwell precisely upon realism in icon-painting raises another fundamental ideological problem. Icon-painting is, of course, primarily religious art, but for Soviet purposes it requires justification in non-religious terms, for example for its ability to express 'national feeling' and to incorporate elements from folk art and everyday life. If it can also be given political significance, so much the better. Thus we are told in the 18th century Byelorussian icon-painting, 'being an Orthodox tradition, was kept up as one of the national liberation struggle forms' (English text, p. 14). It is suggested that traditional iconography was preserved out of political necessity, but the real function of icons and the reasons for compositional conservatism are barely touched upon. Other ideological commonplaces include the 
claim that the 18 th-century Partitions were of 'great progressive significance' for Byelorussia (p. 8) and that mid-17th-century Ukrainian influences resulted from the joint fight of kindred peoples for unification with Muscovy (p. 7).

In comparison portrait painting presents fewer ideological pitfalls. This branch of art, we are told, sprang from the wealth and aspirations of the slachta and revealed 'bourgeois philosophy domination'. It is interesting that some emphasis is laid upon the influence of iconpainting techniques, which brought 'national features' to what might otherwise be regarded as an essentially alien and imported art form.

And so one may pass to the illustrations, which it is quite possible to enjoy without too much ideological hair-splitting. In the religious sections most people will be drawn to the icons, as comparatively few frescoes are illustrated (none, it appears, have survived from the 13 th15 th centuries) and they are, in any case, less easy to appreciate on the printed page detached from their architectural background. The trompe l'oeil effects of the frescoes in the Jesuit Cathedral of Christ's Body in Niaśviž, for example, must be particularly impressive in real life. Most of the icons are illustrated for the first time and even relatively familiar ones, such as the 16th-century Paraśkieva (ill. 26) are seen in closer detail than previously. What will probably strike the reader who is already familiar with Russian icons, which are widely available in both the original and in reproduction, is how distinct the Byelorussian ones are. A number of features stand out - for example, the gold brocade-effect backgrounds, the colour range (in some reds, oranges, yellows, in others a predominantly blue-green palette), the proportions of figures and faces (more rounded, less elongated and severe than Russian counterparts), the precision of decorative detail and the stylization of compositions.

The concept of 'realism' in Byelorussian icons needs some qualification. It is true that elements of naturalism appear somewhat earlier than in Russia, but this often goes hand in hand with a high degree of decorativeness and stylization, e.g. in the carefully composed robes and scroll of Paraśkieva (ill. 26) and the intricate patterns on the robes of the 17th-century Virgin Hodigitria (ill. 27). In one of the bestknown of Byelorussian icons, Pietr Jaŭsiejevič's Nativity of the Virgin (1649; ills 33-5) the figures appear to enact a scene from everyday life and fabrics even feature local folk designs, but the composition and perspective remain stylized and through the window one sees not a realistic landscape but a sky of gold brocade. A later icon, the Virgin of the Life-Giving Stream (17th-18th C; ills 61-3) employs realistic details in figures, architecture and landscape, but the composition is far from naturalistic - the figures and buildings, interspersed with Baroque whirls and curves, are arranged to produce the maximum decorative impact. In the 18 th century one observes two trends, neither of which are illuminated by the concept of 'realism'; on the one hand, a primitive school (see, for example, ills. 71, 73, 75, 79 and in particular the simple direct images from the Life of Christ icons from the church at Sarašova - ills 93-108), on the other hand, the 
highly professional-looking and intricately detailed icons of M. V. Managramist (ills 80-5).

It is worth pointing out that many of the icons were restored in the 1970 s, that the vast majority belong to the collection of the Byelorussian State Museum of Art in Minsk and that in many cases dating is still only approximate. Scholarship on Byelorussian icons still lags behind that on Russian ones in the attribution of works to specific local schools and periods.

Coming straight after the icons, the generally less colourful images of solemn magnates are bound to be something of a disappointment, although the connoisseur of costume will be fascinated by the familiar European fashions - Elizabethan-style hooped dresses and ruffs, 16th17 th-century lace cuffs and collars. The juxtaposition, however, illustrates the undoubted influence of icon-painting upon secular genres. One observes, for example, the same intricate decorativeness and similarly frozen poses. Particularly interesting is the incorporation of the familiar gold brocade-work into the portraits, e.g. in the tunic of Krzysztof Wiesiołowski (1636; ill. 127). The same feature appears in the posthumous portrait of the Muscovite tsar Fedor (1686; ill. 148), usually seen in works on Russian art. The brocade robe and intricate detailing offer convincing evidence of the participation of Byelorussian artists who, as is well known, went to Moscow in considerable numbers in the latter half of the 17th century. Echoes of icons also appear in the 'primitive' portraits, e.g. Jaŭfrazina Tyškievičava (ill. 142) and Sofija Darateja (ill. 153).

All in all, this is a rewarding book which whets the appetite for more. The complex question of foreign influences and cross-currents, hinted at in the introduction - from Russia, the Ukraine, the Balkans, Western Europe - naturally remains unanswered in a work which is primarily illustrative. Similarly one is bound to be curious about the genres which are not illustrated -17 th-18th-century Orthodox and Uniate frescoes, pre-16th-century icons, 17th-century Catholic paintings and secular painting apart from portraits. It will be interesting to see whether the repositories of the Minsk Art Museum will yield up any examples.

Jakimovič's book on the wooden architecture of Byelorussian Paleśsie, published under the auspices of the Institute of Art, Ethnography and Folklore of the Academy of Sciences of the BSSR, comes in more modest format. It is, however, well produced on good quality paper with clear black and white photographs and line drawings and deals with a topic which might be considered even more integral a part of Byelorussian history than icon-painting. For centuries practically everyone in Byelorussia lived in wooden houses, from primitive one-roomed cottages or chaty, constructed in pioneering spirit by their owners, to the 18th-19th-century mansions designed by professional architects. The majority also worshipped in wooden churches. This book deals with the buildings of a region which has been described as a 'unique ethnographic zone', which by virtue of its geographical location experienced many stylistic and constructional cross-currents 
and also preserved its traditions for longer than some other areas. Jakimovič's survey is divided into three sections: section I examines the 'roots' of wooden architecture and lists some of the commonest constructional and decorative devices. (The uninitiated would probably appreciate more systematic diagrams.) Sections II and III observe the conventional ideological priorities by looking first at domestic then at ecclesiastical buildings. The wooden architecture of Paleśsie shared common characteristics with that of Eastern European neighbours, notably the use of the framework (zrubnaja) technique, in which basic rectangular units were constructed from logs laid horizontally and interlocked at the ends. Yet there were many local variations, e.g. the design of roofs in domestic buildings (there is some debate over whether simple pitched or hipped roofs were indigenous), carved decorative details and practical features, such as the location of the stove (next to the entrance in Byelorussia, opposite it in Northern Russia).

Picturesque though many of the domestic and civic buildings are, most readers will probably be more attracted by the churches. There is no consensus about the classification of types, but Jakimovič distinguishes three basic designs: firstly, the simple 'basilical' type (padoüžnavosievaja kampazicyja), close to domestic buildings in its elongated rectangular ground-plan made up of one or more units, usually covered with a pitched or hipped roof; secondly, tiered churches (jarusnaja kampazicyja) formed of a basic square ground-plan with varying number of annexes and topped with one or more tiered towers. One of the most prevalent designs has three towers on an east-west axis, e.g. the Church of St Michael in Rubel (1796; pp. 121-2) and the Church of the Nativity of the Virgin in Lenin (sic!) (1788; p. 123); thirdly, cruciform churches (kryžovyja chramy) featuring a centralized plan with annexes on all four sides of the central square. Most of these incorporate Baroque features and achieve highly decorative effects, e.g. the Church of St Nicholas in Kažan-Haradok (1818; p. 128); There are many variations, for example churches with twin-towered western façade on the Catholic Baroque model and churches with naves and aisles. The appearance of these basically 'stone' traditions illustrates the pressures exerted by stone architecture in the 18th century. In wooden domestic building this led to the incorporation of classical columns and porticoes. Incidents of the influence of earlier 'stone' styles, notably Gothic and Renaissance, are much rarer, probably because few buildings have survived.

As a handbook, Draŭlanaje dojlidstva biełaruskaha Paleśsia has a number of shortcomings, e.g. absence of maps, index and glossary of terms, but the text is authoritative, drawing upon archival sources, and not too much hampered by ideology. It appears to be taken as read that the traditions of wooden architecture were 'progressive and democratic' (p. 150).

One aspect of wooden building not treated in Jakimovič's book is defensive or fortified architecture. For obvious reasons the wooden forts and stockades of early times were replaced with sturdier stone 
or brick structures when resources allowed, and so castles must be seen primarily as examples of the engineer's and stonemason's art. M. A. Tkačoŭ, a teacher at Hrodna University and the leading authority on Byelorussian defensive architecture, has written two books, both in Byelorussian, which between them give a detailed picture of this vital area of Byelorussian architectural history.

The first of the books, Zamki Bielarusi, was sponsored by the Byelorussian Society for the Preservation of Monuments of History and Culture and provides a popular guide to the 15 castles and fortresses and the important group of fortified churches that it illustrates. Each monument is individually examined, with details of its constructional features and history. Particularly useful is the inclusion of old enIgravings and photographs showing the condition of monuments at various periods. In some cases artists' reconstructions are added, throwing poignant light upon the poor state of preservation of all but a handful of the earlier structures. Some of the originally most complex and impressive, e.g. the castlc at Navahrudak (13th-16th centuries), withstood Tatar attacks in the 16th century only to be reduced to a heap of rubble in the 17th. It is not hard to see why the conventional ideological significance attached to such buildings is as patriotic symbols of the heroism and suffering of the Byelorussian nation. Later castles, especially private ones, fared better. The impressive fortress at Mir, for example, has retained its basic outlines until the present day and is now being restored on the basis of an inventory dating from 1686.

The second book, published by the Institute of History of the Academy of Sciences of the BSSR, overlaps with the first but lists some 40 monuments and is obviously intended for a more specialist audience (hence the less attractive format). It includes a bibliographical essay which, in passing, denounces the 'nationalistic' views of the 19th-20th-century Polish scholars but acknowledges the considerable contribution made by antiquarians before the Revolution. It gives a wider perspective on categories of buildings against the background of the wars which prompted the construction of defensive architecture. Changes in design (e.g. the introduction of Italian-style bastion defences in the 16th century) are viewed against innovations in engineering, ballistics and the art of warfare. In both books it is possible to observe the transition from the unadorned buildings of purely defensive function (e.g. the castles at Lida and Kreva) to fortified structures, in some cases little more than thick-walled mansions with token corner turrets and buttresses (e.g. Hajciuniški). In contrast to the starkly utilitarian early fortresses, later examples like the palace-castle in Niaśviž, built at the end of the 16 th century by G. M. Bernardoni, incorporate a variety of elegant devices. Many influences made themselves felt in castle building, e.g. Gothic door and window apertures and vaulting, Renaissance columns, Baroque ornamentation. The wide range of defensive needs which Byelorussia's history and location prompted is well illustrated by the fortified churches, not 
only the well-known examples at Synkoviči, Małaje-Mažejkava and Supraśl but also Protestant and Catholic ones.

Between them the four books reviewed above illuminate three of the most essential aspects of Byelorussian art history, namely icons, wooden architecture and castles, all of which owed their proliferation and their special characteristics to local historical and ethnographic conditions. As Vysockaja writes at the close of her book: 'Byelorussia played a significant role in the network of international artistic links in transmitting artistic influences from south and west to east and from east to west'. But recently published materials suggest that Byelorussia was more than a cultural entrepôt. All these subjects would benefit from a wider comparative approach in order to weigh up the rival claims of influence and individuality. 